\title{
Pracovní právo ve světle kodifikace se zřetelem $k$ jeho zásadám
}

\author{
Tereza Blažková
}

Právnická fakulta, Univerzita Karlova

Kontaktni e-mail: tereza.stara@seznam.cz

Labour Law in the Light of the Codification with Particular Concern to the Labour Law Principles

\begin{abstract}
:
Act No. 65/1965 Coll., The Labor Code, was an important milestone in the development of labor law legislation, as it is the first comprehensive codification of labor law. The Code combined effectively labor legislation in the whole Czechoslovakia and replaced the previous fragmented and obsolete legislation. The final form of the Code and as well the modification of labor relations has been considered for a long time because of the importance of such relations on the existential background of workers, but also on the economic situation of the country. Nevertheless, the relations that the Code newly regulated were based on the previous legislation, since they were concluded under the validity and force of this legislation. One of the aims of this work is therefore examine a false retroactivity. Another aim is also to define how these examined changes in the Labor Code are related to the "socialist" constitution of 1960.
\end{abstract}

Keywords: false retroaction; Labour code; discontinuity of law

Klíčová slova: nepravá retroaktivita; zákoník práce; diskontinuita práva

DOI: $10.14712 / 2464689 X .2020 .21$

Financování: Tento příspěvek vznikl na základě plné finanční podpory a je výstupem projektu SVV č. 260358 s názvem: „Kritická analýza pramenů práva se zřetelem na problémy jejich interpretace a retroaktivitu“.

Část př́ispěvku tvoří podklady, které autorka publikovala již v rámci SVV UK č. 260 012/2014 „Rekodifikace právního řádu, justice a správy v 50. letech 20. století“ a SVV UK č. 260 132/2015 „Historické zdroje velkých kodifikaci““. Předkládaný text na předchozí tematicky navazuje a dále je rozvíjí. 
Pracovní právo má v českých zemích bohaté historické kořeny a prošlo řadou vývojových etap. Vzhledem k unikátnosti pracovněprávních vztahů nemůže být pochyb o nesporném významu pracovněprávního zákonodárství. V roce 1949 například napsal odborník na pracovní právo, Jiří Chyský: „Obor práva pracovního je z nejdůležitějších právních oborů, protože přináší jistotu právě do těch vztahů mezi lidmi, které mají závažnost existenční pro převážnou většinu těch, kdo jsou subjekty pracovního práva."1

Úprava pracovního práva přináší jasné podmínky do takových právních vztahů, které mají př́imou souvislost s existenčními podmínkami člověka. Společnost proto postupně seznala, že právní vztahy týkající se závislé práce jsou vztahy natolik specifického rázu, že zasluhují zvláštní právní úpravu. Přesto, že již koncem čtyřicátých let existovala myšlenka jednotné kodifikace pracovního práva, a dokonce byly započaty i př́pravné legislativní práce, ${ }^{2}$ přijetí jednotné právní úpravy nastalo až o více než dvě dekády později. Tuto úpravu představoval zákon č. 65/1965 Sb., zákoník práce.

Tím započala pro československé pracovní právo nová epocha. Byl to historicky první zákoník práce a zakotvoval pracovní právo v jednotném souhrnném celku. Skloubil organicky pracovněprávní úpravu v českých zemích i na Slovensku a nahradil předchozí roztříštěnou a zastaralou právní úpravu. ${ }^{3}$

Z toho celkem logicky plyne, že zákoník práce představoval pro československé pracovní právo významné zásahy do v té době fungujícího stavu. Vztahy, které zákoník nově upravoval, nicméně vycházely z předcházející právní úpravy, nebot' byly uzavřeny za platnosti a účinnosti této právní úpravy. Pracovněprávní vztahy uzavřené dle předchozí právní úpravy byly podřizeny nově přijatému zákoníku, jedná se tedy o nepravou retroaktivitu. ${ }^{4}$ Problém retroaktivity je o to zajímavější, že jde o vztahy, které, jak již bylo výše uvedeno, mají „existenční závažnost" pro většinu lidí. Cílem tohoto příspěvku je proto vymezit nejdůležitější změny, které zákon č. 65/1965 Sb., zákoník práce, př́inesl.

Významným kodifikačním procesům nezřídka předchází změna právního předpisu nejvyšší právní síly - ústavy. Nejinak tomu bylo také v souvislosti s přijetím pracovněprávního kodexu v šedesátých letech. Dílčím cílem studie je tedy vymezit, jaké mají tyto zkoumané změny v zákoníku práce vztah k ,socialistické“ ústavě z roku 1960.5

\section{Ústava, pracovní právo a kodifikace}

Ústava představuje pomyslný vrchol právního řádu. Jejím prostřednictvím společnost petrifikuje hodnoty, které tvoří její myšlenkový základ, at’ již skutečný nebo spíše jen proklamovaný. Z této představy nevybočuje ani ústavní zákon č. 100/1960 Sb., Ústava Československé socialistické republiky: „Ústava Československé republiky je jejím základním zákonem. Jsou v ní vyjádřeny v podobě zákona myšlenky a představy o uspořádání základů celé naší společnosti a státu. Je v ní projevena vůle pracujícího lidu, jak mají být uspořádány základní vztahy a základní instituce republiky, jakými zásadami se má to uspořádání ř́ídit. Jsou to vztahy a instituce, které určují přímo povahu celého našeho

1 CHYSKÝ, J. Pracovní právo v kostce. Praha: Práce, 1949, s. 5.

2 Blíže viz BLÁHOVÁ I. - BLAŽEK, L. - KUKLÍK, J. - ŠOUŠA J. Právnická dvouletka. Rekodifikace právního ř́ádu, justice a správy v 50. letech 20. století. Praha: Auditorium, 2014.

3 KALENSKÁ, M. a kol. Pracovní právo v nové soustavě rízení: za vyšší úroveñ plánovitého řízení. Praha: Nakladatelství politické literatury, 1965, s. 28.

$4 \quad$ K tomu blíže např. KNAPP, V. Teorie práva. Praha: Beck, 1995, s. 162.

5 Ústavní zákon č. 100/1960 Sb., Ústava Československé socialistické republiky. 
hospodářského, společenského a politického zřízení, celý jeho demokratický a socialistický charakter, socialistické funkce a cíle, formu a celkovou organizaci, poměr k třídám naší společnosti i k jednotlivým občanům, i poměr k jiným státům. “6

Ústavu je možno chápat jako výsledek vývoje určitých společenských hodnot a jejich završení v podobě ústavního textu nebo jako předobraz dalšího vývoje a směru, kterým se má společnost v dalším období ubírat.

Ústava z roku 1960 představovala první zmíněný př́istup. Byla chápána jako důsledek završení vývoje společnosti směrem k socialismu. To bylo vyjádřeno mimo jiné dnes již ikonickým prohlášením v první její části: „Socialismus v naší zemi zvítězil. Vstoupili jsme do nového období našich dějin a jsme odhodláni jít dále k novým, ještě vyšším cílům. Dovršujíce socialistickou výstavbu, přecházíme k budování socialistické společnosti a shromažd’ujeme síly pro přechod ke komunismu. "7

Tato dnes již poněkud přepjatě a pro mladší generace možná dokonce až úsměvně znějící rétorika nezůstávala pouze u prohlášení, ale měla řadu praktických dopadů. Není možné také prodlévat u zkreslených představ o právu v období let 1948-1989 jako o právu vytvářeném pouze a jedině na základě ideologie a tím i (především) pro naplnění ideologických cílů. Podobné představy však někdo mít může, zvláště nahlédne-li na ně, dostatečně nepoučen, současnou optikou. Ideologie zcela jistě zůstávala na pozadí tvorby práva, ovšem do jaké míry byla skutečným vodítkem, které vedlo myšlenky a pero zákonodárce a do jaké míry, naopak zůstávala jen jakýmsi povinným kořením, bez kterého nemohla být polévka hotová, tot' věčná otázka.

Jisté je, že v ústavním zákoně č. 100/1960 Sb., Ústava Československé socialistické republiky, se neoddělitelně míchají oba výše popsané přístupy. Ideologie byla zde integrálně zakomponována a mísila se s realitou fungování socialistické společnosti.

Na jedné straně se hovořilo o vítězství socialismu a budování nového státu osvobozeného díky „hrdinné Sovětské armádě z pout fašistické okupace“. Zdůrazňovány byly především hospodářské úspěchy: „Není již u nás vykořist'ovatelských tříd, vykořist'ování člověka člověkem je vždy odstraněno. Není již hospodářských krizí ani nezaměstnanosti. Vzdělání a kultura se stávají obecným majetkem všech pracujících.“"Vrcholem těchto představ se stala zásada „Každý podle svých schopností, každému podle jeho práce!““8

Na straně druhé je ale nutno zmínit, že tvůrci ústavy nebyli natolik naivní, aby předpokládali, že výše zmíněná zásada dojde praktického naplnění bez dalšího, pokládali-li to vůbec za možné. Obecně byl politický systém charakterizován jako jednota tří základních článků. Těmi byly Komunistická strana Československa, socialistický stát jako mocenský a hlavní nástroj společenských přeměn a také Národní fronta a v ní sdružené společenské organizace a nekomunistické politické strany. To vše mělo být stmelováno vedoucí silou představující základ socialistické a politické státní moci, kterou měla být dělnická třída ve spojení s třídou družstevního rolnictva a socialistické inteligence. ${ }^{9}$ Tento politický systém musel mít ale rovněž praktickou rovinu, která by umožnila reálný výkon moci. Dalo by se samožrejmě rozebírat, jak efektivní ve skutečnosti byl.

6 JIČÍNSKÝ, Z. - LEVIT, P. Socialistická ústava ČSSR: ucelený výklad ústavy. Praha: Státní nakladatelství politické literatury, 1961, s. 9.

7 Ústavní zákon č. 100/1960 Sb., Ústava Československé socialistické republiky.

8 Tamtéž.

9 FLEGL, V. Ústavní základy Československé socialistické republiky. Praha: Svoboda, 1981, s. 15. 
Obdobně bylo také pracovní právo a jeho vztah ke společnosti, vyjádřený výše zmíněnou zásadou odkazující na konkrétní možnosti a potřeby každého jedince, nutno prakticky realizovat. Ústava se tak stala jednoznačným podkladem pro již dlouho připravovanou kodifikaci pracovního práva, což je doloženo například řadou přímých odkazů na pracovněprávní problematiku v ústavě.

Je samozřejmě otázkou, do jaké míry zákonodárce při vytváření ústavy počítal s následnou kodifikací pracovního práva a jestli tomuto faktu byl ústavní text př́mo přizpůsoben. Vzhledem k tomu, že př́íprava kodifikace již byla předtím několikrát na stole, se lze pravděpodobně domnívat, že př́slušná ustanovení ústavy mohla být vytvářena s tímto předpokladem. Dalším podkladem pro toto tvrzení mohou být i zmíněné prrímé odkazy k pracovnímu právu.

Velmi důležitý je v rámci zkoumané problematiky čl. 7 odst. 3, který vymezuje společenský rozměr práce (,ve prospěch celku“), ale zároveň přidává i subjektivní rovinu („ve prospěch pracovníka samého“). Ustanovení článku 15 a 21 pak v rovině pozitivního oprávnění hovoří o postupném zkracování pracovní doby v závislosti na ekonomické úrovni, ale zároveň o nezkracování mzdy. Čl. 17 představoval regulativ ve formě dohledu státních a společenských organizací na pracovní kázeň. Významné byly z hlediska pracovního práva také čl. 22 a 23, které zakotvily odpočinek po vykonané práci, placenou dovolenou a právo na ochranu zdraví a zároveň péči státu a společenských organizací o předcházení vzniku nemocí, celou organizaci zdravotnictví a péči ve formě nemocenského pojištění a důchodového zabezpečení. Ustanovení čl. 26 a 27 zahrnovala zvláštní pracovní podmínky pro mládež a rovnoprávné postavení žen v práci, ale zároveň zvláštní podmínky pro ženy v těhotenství a mateřství.

Toto přímé ukotvení některých pracovněprávních zásad přímo v ústavě bylo velkou novinkou a svědčí o míře důležitosti, jaká byla pracovnímu právu a jeho hodnotám přikládána. Zároveň lze vyjádření př́ímo v ústavní listině vykládat také jako zdůraznění potřeby nové úpravy pracovního práva. Tento požadavek zněl př́imo z nejvyšších míst. Byl formulován např́iklad na plenárním zasedání Ústředního výboru Komunistické strany v prosinci 1960: „Zdokonalení našeho právního řádu vyžaduje v současné etapě, aby právní úprava některých důležitých společenských vztahů byla uvedena v soulad s potřebami rozvoje vyspělé socialistické společnosti. Stále většího významu nabývá oblast socialistického práva, která upravuje vztahy občanů v procesu společenské práce. V socialistické společnosti je pracovní právo zárukou práv pracujících a zároveň aktivním nástrojem rozvoje socialistických výrobních vztahů i výchovy pracujících mas. Musí vyjadřovat soulad zájmů jednotlivců se zájmy společnosti. Je především úkolem, aby pracovní právo bylo vybudováno ve všech svých oblastech na socialistických principech a uvedeno v soulad s novou socialistickou ústavou." 10

V úvahách o formě uvedení pracovního práva v soulad s ústavou z roku 1960, která se jej explicitně dotýkala, je nutné se zaměřit také na povahu pracovního práva v tomto období. V materialisticky orientované společnosti socialistického Československa bylo na lidskou práci pohlíženo jako na jednu ze základních společenských hodnot a s tím souvisel i důraz kladený na právní úpravu právních vztahů, které se lidské práce a jejího

10 In: MǍ̌íK, V. Stav československého pracovního zákonodárství a jeho současné úkoly. Právník, 1961, č. 3, s. 232-247, s. 233. 
využívání týkaly: „Československé pracovní právo jako soubor právních norem upravuje vztahy účasti občanů na společenské práci. [...] Má praktický význam pro každodenní život občanů. Přichází s ním do styku v podstatě každý práceschopný občan. Jako každé právo v objektivním slova smyslu (soubor právních norem) je výrazem vůle dělnické třídy a ostatních pracujících upevňovat a rozvíjet socialistické výrobní vztahy a zabezpečovat stále dokonalejší uspokojování potřeb všech členů socialistické společnosti."11

Lidská práce byla tedy v Československu chápána spíše jako bohatství a prostředek k dosahování profitu celé společnosti, nikoli jednotlivce. Potlačen byl soukromoprávní prvek v pracovním právu. Pracovněprávní poměr přestal být svou povahou soukromou záležitostí: „Základním zdrojem rozvoje socialistické společnosti a blahobytu jejího lidu se stala osvobozená lidská práce. O ni se opírá rostoucí rozvoj národního hospodářství a rostoucí hmotná a kulturní úroveň všech občanů. Jako člen socialistické společnosti se každý pracující účastní na plnění úkolů socialistické výstavby a podílí se na výsledcích společenské práce."12 V souladu s obecným vývojem společnosti byla tedy lidská práce pojímána nikoli jako výsostné právo každého člověka, ale naopak jako celospolečensky prospěšná, a tedy nutná činnost. Od toho se odvíjela také výraznější potřeba veřejnoprávní regulace takových právních vztahů.

Podle některých teoretiků socialistického pracovního práva se pracovní zákonodárství „za kapitalismu značně rozvinulo“. ${ }^{13}$ Tento rozvoj měl ale být: „V převážné většině ústupkem vynuceným bojem proletariátu. Buržoazie se k němu odhodlává, jen když se cítí ohrožena a není vyhnutí‘. 14

Tzv. kapitalistické pracovní právo nemohlo podle socialisticky smýšlejících pracovněprávních teoretiků poskytovat dostatečné záruky pracujícím, nebot' mu chyběla jednotnost a koherentní propracovanost propojeného celku. Teprve socialistické pracovní právo mělo poskytovat správné záruky a jistoty pro pracujícího člena společnosti. To mělo být dostatečně zajištěno povahou socialistického práva. ${ }^{15}$

Pracovní právo mělo mít proto funkci na jednu stranu řídící, na stranu druhou edukativní a mělo pracující vychovávat $\mathrm{k}$ odpovědnému přístupu k práci: „Socialistické pracovní právo se musí stát aktivním nástrojem rozvoje socialistických výrobních vztahů a komunistické výchovy pracujících zejména k dobrovolnému a uvědomělému dodržování pracovní kázně a k bezprostřední účasti na řízení výroby a správě národního majetku. "16

Tento přístup naznačuje oproti předchozímu chápání pracovního práva značný posun. Zvýšenou měrou je akcentována ochrana a vedení zaměstnance a jeho záruky, ovšem za cenu omezení jeho dispozice s vlastními možnostmi.

Požadavek dostatečných záruk pro pracujícího člena společnosti měla naplnit až jednotná kodifikace. Vytváření kodexů, tedy ucelených souborů norem, které systematicky upravují problematiku jednoho právního odvětví, je jedním z projevů kontinentálního typu

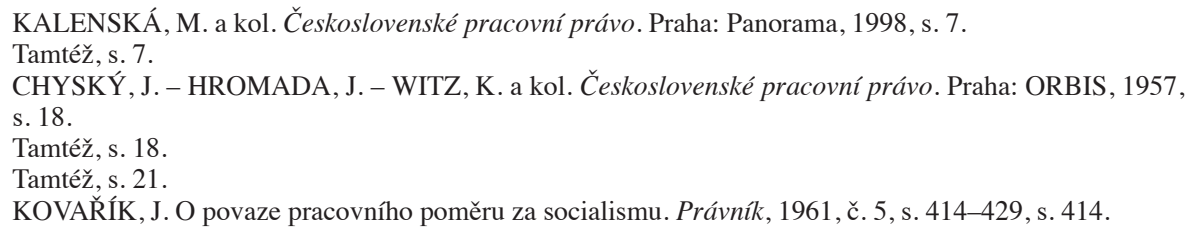


právní kultury. Kodexy se od zákonů neliší právní silou, ale svým faktickým významem. ${ }^{17}$ Pracovní právo svým významem předpoklad pro úpravu v rámci kodifikace jednoznačně splňovalo. Důvod absence kodexu byl spatřován v jeho původu (mělo být produktem vynucených ústupků ze strany zaměstnavatelů) a z toho plynoucí nekoncepčnosti a nejednotnosti pracovněprávní úpravy. Vybudování nové soustavy pracovního práva v podobě kodifikace podle direktiv Komunistické strany Československa, na socialistických principech, mělo „uvádět v život naši novou ústavu“. ${ }^{18}$

\section{Pokusy o kodifikaci}

Úprava pracovněprávních vztahů byla do přijetí jednotného zákoníku stále v obecné rovině řešena rakouským obecným zákoníkem občanským z roku 1811 (úprava námezdní smlouvy zahrnující v sobě služební smlouvu a smlouvu o dílo). ${ }^{19}$

Po převzetí moci do rukou komunistické strany v roce 1948 byl nicméně realizován rozsáhlý pokus o rekodifikaci hlavních právních odvětví v letech 1948-1950, dnes známý jako „,právnická dvouletka“. ${ }^{20}$ Pracovní právo v rámci tohoto projektu kodifikováno nebylo. Nicméně archivní dokumenty, které se nacházejí ve fondech ÚV KSČ v Národním archivu, prokazují, že legislativní práce na zákoníku práce započaly již v této době.

Jedná se především o dokument s názvem „Návrh zásad pro zákoník práce“, který se nachází ve fondech ÚV KSČ v několika zněních a který, ač dataci postrádající, pochází s největší pravděpodobností z roku 1949. Tyto zásady již vykazují významné shody s později přijatým zákonem č. 65/1965 Sb., zákoníkem práce. ${ }^{21}$ Vzorem pro vytvoření výše zmiňovaných zásad pro budoucí zákoník práce bylo i sovětské právo, nebot' byly v archivu dohledány studijní materiály k pracovnímu právu, které pracují s překlady sovětských děl. Jedná se např́íklad o přeloženou učebnici „Základy práva pracovního“, která byla vydána Právnickým institutem Akademie věd SSSR. ${ }^{22}$

Další kodifikační pokus proběhl patrně koncem 50. let. Je možno tak soudit opět s ohledem na dostupné archivní materiály. V nezpracovaném fondu Ministerstva spravedlnosti v Národním archivu se totiž nacházejí materiály z roku 1957, které svědčí o probíhajících kodifikačních pracích. ${ }^{23}$ Vypracováním kodexu práce byla pověřena Ústř̌ední rada odborů (ÚRO). Na půdě Ústřední rady odborů byly k tomuto účelu vytvořeny pracovní komise. Legislativní práce probíhaly v součinnosti s Ministerstvem spravedlnosti. ${ }^{24}$

Úkolem navrhované osnovy mělo být: ,„především sjednotit na socialistických zásadách dosud roztřrištěné platné pracovněprávní předpisy, zpřesnit a zjednodušit právní úpravu pracovních vztahů a odstranit vývojem překonané předpisy. Jde o to, aby zákoník práce přehledně a srozumitelně vyjádřil práva a povinnosti pracujících i vedení podniků a pomáhal jim při plnění úkolů naší výstavby, při upevňování poměru pracujících k práci, k závodu

18

19

20

21

22

23

24

GERLOCH, A. Kodifikace. In: HENDRYCH, D. a kol. (red.). Právnický slovník. Praha: C. H. Beck, 2009, S. 330 .

MAŘÍK, $c . d .$, s. 247.

BĚLINA, M. Pracovní právo. Praha: C. H. Beck, 2012, s. 29.

BLÁHOVÁ - BLAŽEK - KUKLÍK - ŠOUŠA, $c$. $d$.

K tomu blíže viz BLÁHOVÁ - BLAŽEK - KUKLÍK - ŠOUŠA, c. d., s. 147.

NA, fond ÚV KSČ, dílčí fond Právnická komise (č. 29), a. j. 287. Návrh zásad pro zákoník práce.

NA, fond Ministerstvo spravedlnosti (nezpracováno). Legislativa - zákoník práce 1957.

Bohužel nejsou uvedena celá jména: In: NA, fond Ministerstvo spravedlnosti (nezpracováno). Legislativazákoník práce 1957. 
a k potřebám celku, a tak přispíval ke zvýšení hmotné a životní úrovně pracujících. Proto dosah a význam zákoníku práce jak pro pracující, tak i pro celé naše hospodářství bude velmi závažný.“"25

Vypracovaná osnova zákoníku práce byla již v květnu 1957 připomínkována. Právnický ústav ministerstva spravedlnosti v čele s vedoucím dr. Ladislavem Bydžovským předložil rozsáhlý seznam připomínek. Ty se týkaly především závažných nedostatků při řešení pracovněprávních sporů. ${ }^{26}$ Dle stanoviska ministerstva bylo cílem, aby se většina pracovně-právních sporů řešila na půdě rozhodčích komisí, nikoli již prostřednictvím soudního řízení. Většina sporů se měla tedy rozhodnout přímo v závodě, což mělo vést také $\mathrm{k}$ tomu, že účastníci sporu se měli rozhodnutí rozhodčí komise dobrovolně podřídit. Proto měla činnost rozhodčích komisí spočívat především na zásadě přesvědčovací, čímž se mělo eliminovat nebezpečí zneklidnění mezi zaměstnanci. ${ }^{27}$

Vypracovaná osnova zákoníku práce z roku 1957 měla rozvádět ústavní zásady socialistického pracovního práva, kterými bylo právo všech občanů na práci, rovnoprávnost muže a ženy při práci, spravedlivé odměny za práci podle množství, jakosti a společenského významu práce. Dále měla reflektovat právo na ochranu zdraví a bezpečnost při práci, právo na zvláštní ochranu žen a mládeže při práci, právo na odpočinek po práci a na zotavenou a ,aby se v socialistickém pracovním poměru rozvíjela vyšší morálka nového člověka a jeho nový vztah k práci a k socialistickému vlastnictví, aby socialistické pracovní poměry byly mocnou tvưrčí silou při ve výstavbě socialistické společnosti a přispívaly ke zvýšení životní úrovně pracujících“. 28

Tato osnova z roku 1957 nakonec přijata nebyla. Důvodem pravděpodobně byly, kromě problematické úpravy řešení pracovně-právních sporů, stejně jako u té z roku 1949, hospodářské dopady, které by přijetí nového pracovně-právního kodexu mělo ve vztahu k ekonomické úrovni tehdejšího Československa. Pro tuto teorii svědčí archivní materiály, v nichž se nachází řada dotazníků a statistických šetření, které měly monitorovat a dokumentovat ekonomický dosah opatření zákoníku práce.

Pro tuto teorii hovoří i korespondence osob zainteresovaných na př́pravě nového pracovněprávního kodexu. Dne 13. května 1957 napsal předseda vlády Viliam Široký ministrovi spravedlnosti dr. Václavu Škodovi: „Vzhledem k závažnosti a významu zákoníku práce považuji shodně s předsedou Ústřední rady odborů Zupkou za nutné, aby předložený materiál byl ve Vašem resortu prověřen nejen z hlediska právní formy, ale zejména z hlediska hospodářské únosnosti a politického dosahu navrhovaných úprav.“29

Z výše uvedeného citátu je jasně patrné, že existovaly obavy, jak se nový pracovněprávní kodex prakticky promítne do hospodářského života Československa, a vyskytly se pochybnosti, zda je vůbec ekonomická úroveň země na takovýto zákoník připravená.

25 NA, fond Ministerstvo spravedlnosti (nezpracováno). Legislativa - zákoník práce 1957. Přípis předsedy ÚRO ministrovi spravedlnosti ze dne 2.5. 1957.

26 NA, fond Ministerstvo spravedlnosti (nezpracováno). Legislativa - zákoník práce 1957. Připomínky právnického ústavu ministerstva spravedlnosti předkládané dr. Ladislavem Bydžovským, vedoucím legislativního odboru Ministerstva spravedlnosti.

27 NA, fond Ministerstvo spravedlnosti (nezpracováno). Legislativa - zákoník práce 1957. Přípis z Ministerstva spravedlnosti s. Zupkovi z předsednictví ÚRO.

28 NA, fond Ministerstvo spravedlnosti (nezpracováno). Legislativa - zákoník práce 1957. Osnova zákoníku práce.

29 NA, fond Ministerstvo spravedlnosti (nezpracováno). Legislativa - zákoník práce 1957. Přípis předsedy vlády ministrovi spravedlnosti v otázce zákoníku práce ze dne 13. 5. 1957. 
I když nakonec obě výše zmíněné osnovy zákoníku práce nebyly přijaty, tvořily minimálně inspirační zdroj a určitý podklad pro vytvoření a přijetí zákoníku práce v roce 1965, který se mohl konečně pokusit naplnit deklarované cíle socialistického pracovního práva.

\section{Zákoník práce a podstatné změny, které přinesl}

$\mathrm{Na}$ začátku šedesátých let začala být již situace na poli pracovního práva neudržitelná. V souvislosti s dalším přetvářením výrobních vztahů a přechodem na plánovitý systém hospodářství zesilovala také potřeba pracovněprávního zákonodárství, které by reflektovalo tyto tendence a konečně provedlo zásady naznačené již koncem čtyřicátých let. Jako výsledek a určité završení fáze budování socialismu byla představována ústava z r. 1960. ${ }^{30}$

Řada pracovněprávních předpisů proto naprosto neodpovídala společenské realitě. To mělo významný dopad především na aplikační praxi: „Tyto zákony vydané v době panství kapitalistického řádu svým obsahem a formulacemi mírily na pracovní vztahy zcela jiné povahy, než byly pracovní vztahy, které se vytvářely v naší společnosti. Aplikace těchto starých předpisů byla složitá, nebot' se často mohla provádět jen pomocí zásad stanovených nejprve v Ústavě 9. května, později Ústavy ČSSR (1960).“31

Další fáze kodifikačních prací probíhala opět na půdě Ústřední rady odborů, do jejíž působnosti náležela př́prava pracovněprávních předpisů. V roce 1962 byly kodifikační práce započaty a v lednu 1963 předložila Ústřední rada odborů k veřejné diskuzi návrh zásad zákoníku práce. Posléze bylo vypracováno také paragrafové znění zákona. $Z$ důvodu hospodářských problémů a následné diskuze o podobě možné ekonomické reformy, bylo k přijetí kodifikace přikročeno až v červnu roku 1965. Není bez zajímavosti, že podobně jako v případě předchozího návrhu, byly pečlivě posuzovány ekonomické dopady připravované kodifikace. ${ }^{32}$

Zákonem č. 65/1965 Sb., zákoník práce, se československé pracovní právo proměnilo od základů a konečně dosáhlo kýžené jednoty a propracovanosti koherentního celku. Zákoník kloubil organicky pracovněprávní úpravu v českých zemích i na Slovensku a nahradil předchozí roztřrištěnou, zastaralou a nevyhovující právní úpravu. Obsahoval krátkou ideologickou preambuli, základní zásady a vlastní tělo zákoníku, jež bylo děleno na šest částí. ${ }^{33}$

Z hlediska nepravé retroaktivity je jasně patrné, že zákoník musel nutně dopadat na pracovněprávní vztahy uzavřené před jeho přijetím. Zákoník práce řešil tento fakt přímo v ustanovení $§ 276$ a následujících. Problém, který ale tato přechodná ustanovení neřešila a který je svou podstatou mnohem důležitější, jsou dopady základních zásad na pracovní poměr. Na to se nyní tato práce zaměří.

Pracovní poměr, který představoval předmět výkladu řady socialistických teoretiků, byl fakticky před přijetím zákoníku uzavírán podle do té doby platné právní úpravy vycházející z liberálních základů pracovního práva s převažujícím soukromoprávním prvkem. K výkladu se ale již užívalo korektivu zásad, které přinesla Ústava 9. května a posléze

\footnotetext{
30 WITZ, K. Československé pracovní právo v období 1945-1975. Právník, 1975, č. 7, s. 636-651, s. 643. Tamtéž, s. 643.

VOJÁČEK, L. - SCHELLE, K. - TAUCHEN, J. a kol. Vývoj soukromého práva na území českých zemí. Brno: Masarykova univerzita, 2012, s. 916-917.

33 KALENSKÁ a kol. Pracovní právo v nové soustavě ř́izení, s. 28.
} 
ústava z roku $1960 .{ }^{34}$ Vrcholem bylo následně přijetí zákoníku práce, který deklaruje snahu řídit a spravovat národní hospodářství (například v preambuli) a nadto výchovné působení v kolektivu pracujících (např́klad ustanovení § 22).

Uvedené dobře demonstruje obrat, který československé pracovní právo prodělalo. Individualita subjektů zaměstnance a zaměstnavatele se rozpustila v podnicích na jedné straně a kolektivech pracujících na straně druhé. Zaměstnanci (pracující) tak již více nevystupují jako jednotlivci, ale organizovaný kolektiv. To velmi přesně vyjádřil Jan Kovařík, když napsal: „Individuální pracovní vztahy mají za socialismu jinou povahu, která se projevuje mimo jiné také v tom, že je nelze oddělit od kolektivních pracovních vztahů a nutno je zkoumat vždy ve vzájemné souvislosti s nimi. “35

Tento posun pracovního práva byl vyjádřen také v článku 11 odst. 3 ústavy z roku 1960, který hovoří o široké účasti pracujících a jejich společenských organizací, zejména Revolučního odborového hnutí na všech stupních řízení při veškeré hospodářské činnosti státních i jiných organizací.

Proměna pracovního práva byla demonstrována také změnou terminologie. Mizí označení „,zaměstnavatel“ a ,zaměstnanec“. Na jejich místo zavedl zákoník práce označení „socialistické organizace“ a „pracovník“. Když se požadavek na změnu terminologie objevil, byl vysloveně spojován nikoli se změnou pouhých slov, ale především šlo o podstatu pracovněprávního vztahu a kvalitativní odlišnost, kterou měl vykazovat socialistický vztah oproti vztahu za „kapitalismu“.36

S ohledem na možné ideologické dopady zákoníku práce lze také zmínit, že zákoník nahradil některé služební předpisy. ${ }^{37}$ Tím ještě více eliminoval služební poměr státních úředníků. To mělo za následek další okleštění jejich nezávislosti a podřízení státu a jeho ideologickým požadavkům. Právě tento fakt se později v roce 1968 v rámci úvah o možných změnách v pracovním právu stal předmětem kritiky a bylo navrhováno, aby byla zvážena zvláštní úprava, jako tomu bylo v minulosti. ${ }^{38}$

Jak již bylo řečeno, nejdůležitější úlohu ve změně podstaty pracovního práva hrály zmíněné základní zásady, které „stejně jako v jiných právních odvětvích a právním systému vcelku [...] mají podstatný význam a tvoří základní pilíře celého pracovního práva“".39 Zásady zákoník práce zakotvuje v samém úvodu v podobě deseti článků, které ale v sobě integrují větší počet zásad. Tyto zásady jednoznačně vycházejí z ústavy, zákoník práce je dále rozvádí a konkretizuje. Všechny mají formu obecného pravidla a tvoří proto výkladový rámec a korektiv pracovního práva. Odrážely se proto na dalších místech zákoníku. ${ }^{40}$

Článek I. stanovil právo a také povinnost k práci a zároveň právo každého jednotlivce k rozvíjení svých schopností a uplatnění oprávněných zájmů podílem na společenské práci. Zákoník práce tímto rozvedl čl. II. ústavy z roku 1960. Jan Kovařík odvozuje tuto zásadu z existence hospodářské soustavy a z postavení jednotlivých občanů v ní. Právo na práci, ale analogicky k tomu také povinnost pracovat od faktu, že jde o ,práci jednotlivých členů

$34 \quad \mathrm{~K}$ tomu např. WITZ, c. d., s. 643.

35 KOVAŘÍK, O povaze pracovního poměru za socialismu, s. 423.

36 Tamtéž, s. 415.

37 Např́iklad vládní nařízení č. 120/1950 Sb., o právech a povinnostech státních zaměstnanců, o řízení ve věcech jejich pracovního poměru a o rozhodčích komisích.

VOJÁČEK - SCHELLE - TAUCHEN a kol., c. d., s. 930.

CHYSKÝ - HROMADA - WITZ a kol., c. d., s. 30.

KALENSKÁ a kol. Československé pracovní právo, s. 48. 
socialistické společnosti, kteří pracují za soudružské spolupráce a vzájemné pomoci se zespolečenštělými výrobními prostředky pro společnost a tím i pro sebe“. 41

Jednotlivec je na základě této zásady ztotožněn se společností, čímž je značně redukována jeho autonomie vůle. Tento vztah by se dal popsat na obráceném předpokladu, že souhrn individuálního „dobra“ vytváří kolektivní „dobro“. Tímto směrem ale uvedená souvztažnost zpravidla nefunguje. Problematičnost uvedeného ustanovení zakotvujícího povinnost pracovat vnímala také dobová právní věda. Ladislav Vojáček k tomu uvádí, že se snažila toto vysvětlit tím, že právo na práci je prvotní a konkrétní, kdežto povinnost pracovat je určena obecně (neplyne z ní konkrétní povinnost). ${ }^{42}$ Tato teoretická představa ovšem praktickou problematičnost zmíněného pravidla zcela neřešila.

Článek II. vycházel z představy socialistické právní vědy o „vykořist’ování“ v rámci pracovních vztahů a zakotvil proto jeho zákaz. Toto ustanovení však bylo spíše proklamativní, protože provedení tohoto pravidla měla zajišt’ovat již samotná podstata socialistického zř́zení.

Článek III. upravoval podmínku souhlasu socialistické organizace a pracovníka při vzniku pracovního poměru. Tímto ustanovením měla být zajištěna smluvní podstata pracovních vztahů. V podmínkách centrálně řizeného hospodářství však představovala spíše reminiscenci skutečné smluvní volnosti, která tvoří podstatu pracovních vztahů v demokratické společnosti. Odkaz na smluvní základ pracovního vztahu měl praktický význam spíše při posuzování projevu vůle při pracovněprávním jednání. ${ }^{43}$

Článek IV. upravoval základ odměny za práci a zároveň povinnost socialistických organizací vytvářet pracovníkům pro výkon práce ty nejlepší možné podmínky. Odměňování pak podrobně upravovala hlavně hlava IV. zákoníku práce. Mzda se měla odvíjet od množství, jakosti a společenského významu práce. Ve skutečnosti však byla řízena státem a její výši stanovily celostátní mzdové předpisy. Takový systém neměl nutně potřebnou pružnost a mzdovou politiku se jako stimulační nástroj nedařilo naplňovat. ${ }^{44}$

Článek V. vycházel z výše citovaného čl. 11 odst. 3 ústavy z roku 1960. Zakotvil povinnost vůči společnosti účastnit se na rozvoji, řízení a kontrole činnosti socialistické organizace a napomáhat k rozvoji a upevňování vztahů soudružské spolupráce a vzájemné pomoci. Jeho druhá část pak odkazem na pracovní podmínky socialistických organizací navazuje na článek IV.

Článek VI. oproti povinnosti socialistických organizací upravuje povinnosti pracovníků. V závěru hovoří o potřebě prohlubovat a upevňovat socialistickou pracovní kázeň. Pojem pracovní kázeň není zákonodárcem přesně definován. Dle Ladislava Vojáčka je sice možné odvodit, že ,jde o soubor právních povinností zabezpečující rádný průběh pracovního procesu“", ale nebyla přesto užívána jednotně. ${ }^{45}$

Články VII. a VIII. představovaly podklad pro zvláštní úpravu podmínek žen a mladistvých a zároveň rovné postavení žen v práci. Z pohledu doby přijetí zákoníku práce představují tyto zásady nepochybně značný progres. Rovnost v postavení ženy a muže se

\footnotetext{
41 KOVǍ̌íK, J. Pracovní právo ČSSR. Praha: Svoboda, 1966, s. 43.

42 VOJÁČEK - SCHELLE - TAUCHEN a kol., c.d., s. 923.

43 KOVAĽÍK, Pracovní právo ČSSR, s. 44.

44 VOJÁČEK - SCHELLE - TAUCHEN a kol., c.d., s. 925.

45 Tamtéž, s. 924.
} 
promítá do celého zákoníku práce. ${ }^{46}$ Ze současného pohledu by bylo přece jen možné se pozastavit nad tím, jak je na jedné straně předkládána rovnost v postavení muže a ženy, ale na straně druhé se automaticky předpokládá, že to bude právě žena, kdo bude primárně vykonávat péči o děti a domácnost.

Výčet zásad uzavíraly článek IX., který upravoval bezpečnost a ochranu zdraví pracovníků při práci, a článek X., který zakotvil účast Revolučního odborového hnutí v pracovních vztazích.

\section{Závěr}

Základní zásady, často formulované již v ústavních textech, předznamenávají směr vývoje právního řádu a jeho jednotlivých odvětví (i když je otázkou, do jaké míry s touto představou pracují sami tvůrci ústavních textů). Podobně tomu bylo také s ústavou z roku 1960, která vytvořila myšlenkový základ pro rozsáhlou rekodifikační vlnu v československém právu. V rámci tohoto kodifikačního úsilí byl konečně přijat také zákoník práce.

Pro pochopení právního předpisu, jeho základu a „ducha“ je především nutné zkoumat jeho myšlenkové pozadí, které tvoří hlavně předmětné základní zásady. Základní zásady zákoníku práce z roku 1965 ukazují razantní rozchod s předchozí převládající představou pracovního práva jako odvětví vycházejícího primárně z práva soukromého.

Po přijetí zákoníku, který se zpětně dotýká do té doby uzavřených a platných pracovněprávních vztahů, tedy nastává z pohledu právní teorie zajímavá situace. Pracovněprávní vztahy vzniklé do té doby byly teoreticky uzavírané dle staré právní úpravy (liberální, soukromoprávní), vykládány podle zásad nových ústav (socialistické) a pak podřízeny novému zákoníku (deklarujícímu rrídící a výchovné funkce).

Tato naznačená diskontinuita ovšem nijak nesnižuje význam zákoníku práce jako klíčového právního předpisu, který vytyčil další směr vývoje pracovního práva v Československu. Už jen z toho důvodu, že se jedná o vůbec první ucelenou úpravu tohoto právního odvětví, které bylo do té doby vždy součástí práva občanského. Teprve vyčleněním z občanského práva se mohlo pracovní právo autonomně rozvinout.

Je samozřejmě otázkou, jakou podobu pro takový právní předpis zvolit. Jak vyplývá právě ze základních zásad, na kterých byl postaven, posunul zákoník práce pracovní právo více směrem $\mathrm{k}$ veřejnému právu. A to vlivem významnější regulace, omezení práv jednotlivce a zdůrazněním jeho postavení v rámci celku.

Tato skutečnost je patrně důsledkem faktu, že každé právo je odrazem doby, která je vytvárí. Pracovní právo se tak stalo nástrojem direktivního řízení společnosti a plánovitého hospodářství, což bylo v kontrastu s jeho genezí a původními myšlenkami. Zůstává nicméně celospolečenskou otázkou a zároveň rozhodnutím, jaké pracovní právo si ta která společnost v daném čase zvolí. Zda takové, které si klade za cíl řídit a vychovávat, nebo takové, které bude produktem vzájemného demokratického diskurzu zúčastněných stran.

$46 \quad$ KALENSKÁ a kol. Československé pracovní právo, s. 52. 